\title{
Acetylation Genotype and the Genetic Susceptibility to Prostate Cancer in a Southern European Population
}

\author{
Sandra Costa, ${ }^{1,2 *}$ Daniela Pinto, ${ }^{2}$ Antonio Morais, ${ }^{3}$ André Vasconcelos, ${ }^{2}$ \\ Jorge Oliveira, ${ }^{3}$ Carlos Lopes, ${ }^{2,4}$ and Rui Medeiros ${ }^{2,4}$ \\ 'ICVS, Life and Health Sciences Research Institute, Health Science School, Minho University, Braga, Portugal \\ ${ }^{2}$ Molecular Oncology/Department of Pathology, Instituto Português de Oncologia - Porto, Porto, Portugal \\ ${ }^{3}$ Urology Department, Instituto Português de Oncologia - Porto, Porto, Portugal \\ ${ }^{4}$ ICBAS, Abel Salazar Institute for the Biomedical Sciences, Porto, Portugal
}

\begin{abstract}
BACKGROUND. Epidemiologic studies have suggested that environmental factors and diet are important risk factors in the pathogenesis of prostate cancer. The $N$-acetyltransferases (NAT) are important enzymes in activation and inactivation of various carcinogens, including those found in well-cooked meat and cigarette smoke.

METHODS. We analyzed DNA samples from 146 prostate cancer patients and 174 healthy men. We used PCR-RFLP method to analyze NAT1 and NAT2 polymorphisms.

RESULTS. We did not find statistically significant differences in NAT1 genotypes frequencies between prostate cancer patients and control group. We observed an association of the slow acetylator genotype, $N A T 2 * 6 / N A T 2 * 6$ with prostate cancer protection $(P=0.017 ; \mathrm{OR}=0.31,95 \%$ CI $0.11-0.84)$. Multivariate logistic regression analysis confirmed this association (0.030; $\mathrm{OR}=0.32,95 \%$ CI $0.12-0.89)$.

CONCLUSIONS. Our results indicate a role of NAT2 polymorphisms in the carcinogenic pathway of prostate cancer, specifically in a population of Southern Europe. Prostate 64: 246252, 2005. (C) 2005 Wiley-Liss, Inc.
\end{abstract}

KEY WORDS: NAT; polymorphisms; prostate cancer; acetylation; heterocyclic aromatic amines

\section{INTRODUCTION}

Prostate cancer is one of the most common malignancies in Western countries, being the second in cancer incidence and the third in cancer mortality among men in Portugal [1]. Several factors are associated with an increased risk for prostate cancer. Epidemiologic studies have suggested that environmental factors, including ultra-violet radiation [2], smoking [3] and diet, including meat and fat intake [4], are involved in the development of prostate cancer. Many chemical and dietary carcinogens, especially heterocyclic amines derived from wellcooked meat, seem to be involved in the pathogenesis of prostate cancer [5].

The $N$-acetyltransferase (NAT) activity enrolls an important step in both activation and inactivation of numerous carcinogens, found for example in wellcooked meat and cigarette smoke, respectively [6]. Therefore, the acetylator status may modify individual response to various chemicals and thus individual cancer susceptibility.

NATs are encoded by two genes, NAT1 and NAT2, located in chromosome 8p 21.3-23.1 [7]. Both genes are highly polymorphic. To date, 29 NAT2 alleles have been identified [8]. Individuals who have two or more NAT2 polymorphisms have a slow acetylator phenotype, individuals heterozygous for NAT2 polymorphisms have a rapid/intermediate acetylator phenotype, and those who lacked NAT2 polymorphisms have a rapid acetylator phenotype. Among all the NAT2 allelic

*Correspondence to: Sandra Costa, ICVS-Health Sciences School, Minho University, Campus Gualtar, 4710-057 Braga, Portugal.

E-mail: sandracostas@portugalmail.com

Received 23 July 2004; Accepted 12 November 2004

DOI 10.1002/pros.20241

Published online 16 February 2005 in Wiley InterScience (www.interscience.wiley.com). 
variants, two $(N A T 2 * 5$ and NAT2*6) were shown to account for most of slow NAT2 acetylator genotypes in Caucasian populations [9]. Previous studies have found associations between NAT2 polymorphisms and cancer risk [10-15].

Polymorphisms in NAT1 yield over 25 variant alleles [8]. A common NAT1 allelic variant (NAT1*10) is associated with increased catalytic activity (rapid acetylator phenotype) [16]. This allelic variant has been associated with increased risk to colorectal cancer, compared with $N A T 1^{*} 4$ homozygotes [17].

It has been reported that human prostate epithelial cells metabolize potential carcinogens [17]. Furthermore, Wang et al. demonstrated the expression of NAT1 and NAT2 transcripts in prostate cells [5]. Therefore, individual susceptibility to prostate cancer may be modified by genetic polymorphisms in NAT1 and NAT2 enzymes. The aim of this study was to assess the association between NAT1 and NAT2 polymorphisms and prostate cancer in a Portuguese population.

\section{MATERIALS AND METHODS}

\section{Patients}

Consecutive patients $(n=146)$ with histologically confirmed prostate cancer (median age 66 years) were enrolled in this study between 1999 and 2000 from the Department of Urology of the Portuguese Institute of Oncology, Porto. Clinical characterization including Gleason grade, disease status, age at diagnosis, and prostate specific antigen (PSA) was obtained from medical records. The control group consisted of 174 healthy individuals with no evidence of neoplastic disease and a median age of 64 years. All participants were Caucasian living in Porto district.

Approximately, $8 \mathrm{ml}$ of venous blood was obtained with a standard venipuncture technique using EDTA tubes. DNA was extracted from the white blood cell fraction from each study subject using a salting-out protocol [18].

\section{Genotyping of NATI and NAT2 Polymorphisms}

For NAT1 genotype analysis we used a PCR-RFLP method already described [19]. PCR conditions was performed as follows: $100 \mathrm{ng}$ of genomic DNA was added to $0.25 \mu \mathrm{M}$ of each primer, $0.2 \mathrm{mM}$ of each dNTP, $1.5 \mathrm{mM} \mathrm{MgCl} 2,1 \times$ Taq buffer and $1 \mathrm{U}$ of Taq DNApolymerase to a final volume of $50 \mu \mathrm{l}$. Thirty five cycles were performed, consisting of $94^{\circ} \mathrm{C}(30 \mathrm{sec})$ for denaturation, $45^{\circ} \mathrm{C}(30 \mathrm{sec})$ for primer annealing, and $72^{\circ} \mathrm{C}$ (45 sec) for primer extension. To differentiate $N A T 1^{*} 4, N A T 1^{*} 10$, and $N A T 1^{*} 11$ alleles, PCR product was subjected to enzymatic digestion with $M b o$ II enzyme. Restriction products were submitted to electrophoresis in 4\% Metaphor high resolution agarose

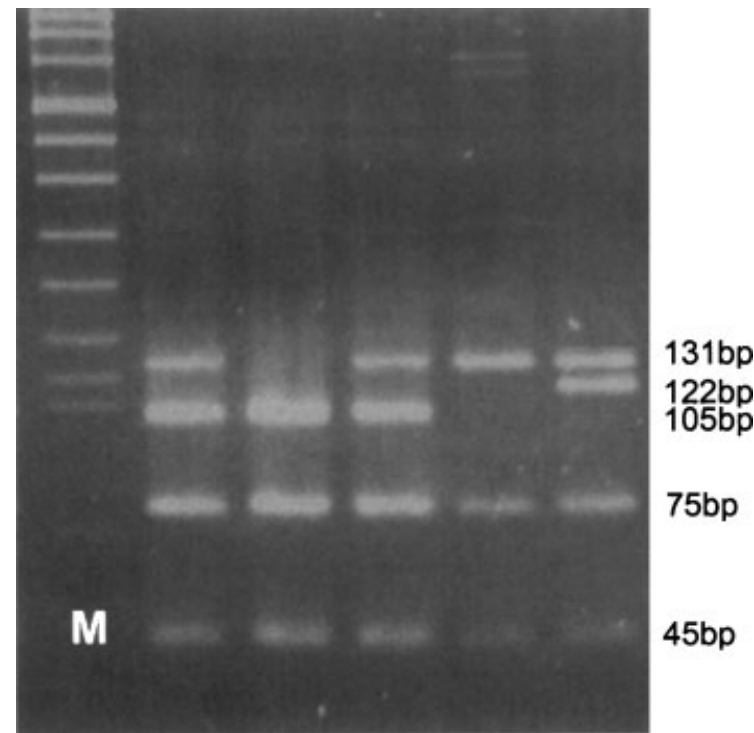

Fig. I. Mbo II RFLPs of the PCR products of the NATI alleles: NATI*4 alleles-105, 7I, 45, and 26 bp fragments, NATI*10 alleleI3I, 75, 45, and 26 bp fragments and $N A T I * I I$ allele-I22, 75, 45, and 26 bp fragments (M-DNA Molecular Weight Marker VIII $\left(\right.$ Roche $\left.^{\mathrm{R}}\right)$ ).

gel (Fig. 1). Digestion of $N A T 1^{*} 4$ resulted in fragments of $105,71,45$, and 26 base pairs (bp), NAT1 ${ }^{*} 10$ in fragments of $131,75,45$, and $26 \mathrm{bp}$. The $N A T 1^{*} 11$ allele can be distinguished by observation of a $9 \mathrm{bp}$ mobility ship of the $131 \mathrm{bp}$ band to a $122 \mathrm{bp}$ band.

Genotyping for NAT2 was carried out using the PCR-RFLP method [20]. The reactions of PCR consisted of nearly $100 \mathrm{ng}$ of genomic DNA, $1 \mu \mathrm{M}$ of each primer, $0.2 \mathrm{mM}$ of each dNTP, $1.5 \mathrm{mM} \mathrm{MgCl}_{2}, 1 \times$ Taq buffer, and $1 \mathrm{U}$ of Taq DNA-polymerase to a final volume of $50 \mu$. Thirty cycles were performed, consisting of $98^{\circ} \mathrm{C}(30 \mathrm{sec})$ for denaturation, $62^{\circ} \mathrm{C}(1 \mathrm{~min})$ for primer annealing, and $72^{\circ} \mathrm{C}(1 \mathrm{~min})$ for primer extension. After amplification, $15 \mu \mathrm{l}$ of PCR was digested with $20 \mathrm{U}$ of the Kpn I and Taq I restriction enzymes (positions 480 and 590) specific for the two different NAT2 allelic variants to be screened (NAT2*5 and NAT2*6, respectively). Restriction products were submitted to electrophoresis in 2\% agarose gels. After digestion with Kpn I, the 481-T (NAT2*5) and 481-C (NAT2*4) alleles were visualized as fragments of $290 \mathrm{bp}$ and 170 plus $120 \mathrm{bp}$, respectively (Fig. 2A). The 590-A (NAT2*6) and 590-G $(N A T 2 * 4)$ alleles were visualized as fragments of 290 and 230 plus $60 \mathrm{bp}$, respectively, after digestion with Taq I (Fig. 2B).

\section{Statistical Analysis}

Analysis of data was performed using the program SPSS for Windows (version 11.0). Chi-square analysis was used to compare categorical variables. A 5\% level significance was used in the analysis. The odds ratio 
A

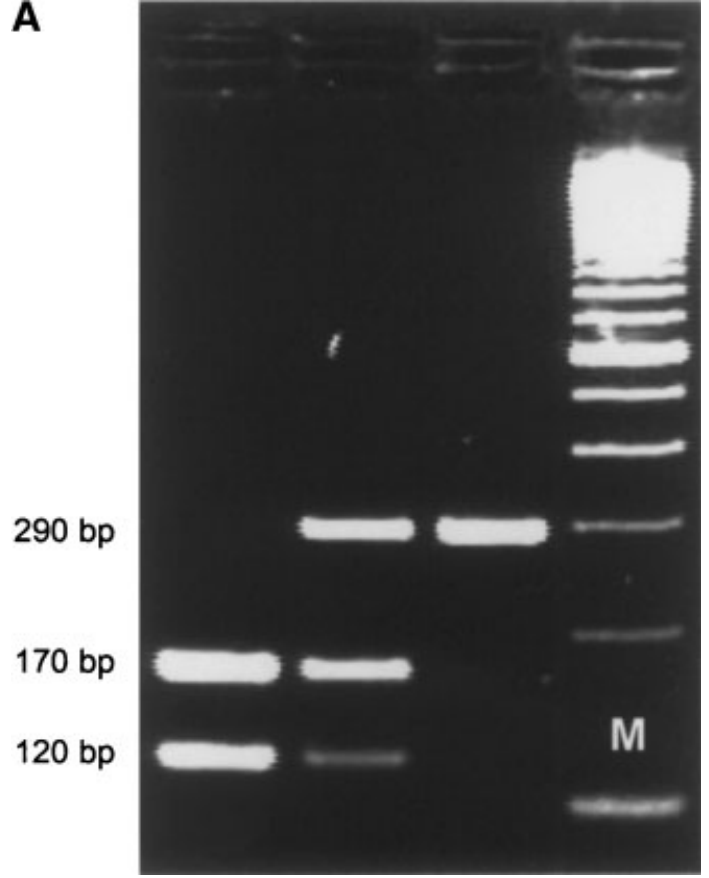

B

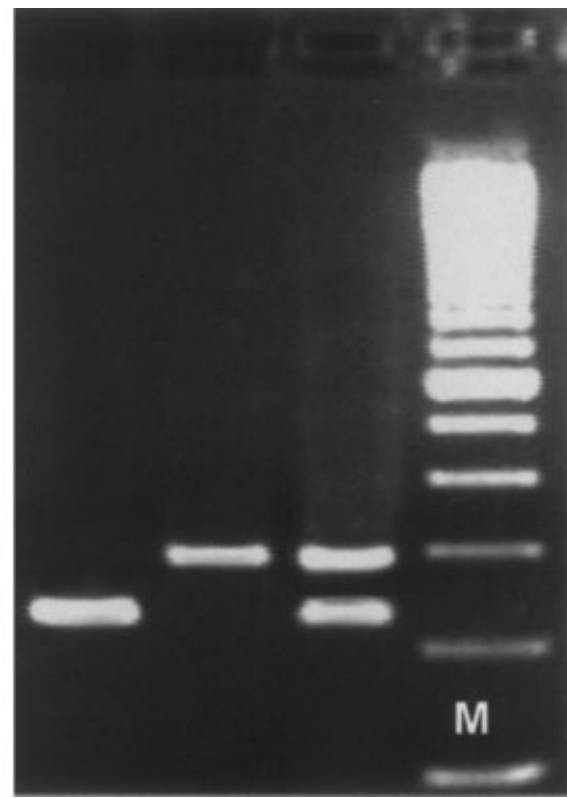

Fig. 2. RFLPof the PCR products of the NAT2 alleles. Kpn I restriction (A) 290 bp fragment-NAT2*5 allele; I70 plus 120 bp fragments -NAT2*4 allele. Taq I restriction (B) 290 bp fragment—NAT2*6 allele; 230 bp plus 60 bp fragments (not visualized)—NAT2*4 allele. (M-100 bp DNA ladder $($ Gibco BRL $)$ ).

(OR) and its $95 \%$ confidence interval (CI) was calculated as a measure of the association between NAT1 and NAT2 genotypes and prostate cancer risk. Multivariate logistic regression analysis was used to calculate the adjusted OR and 95\% CI for the influence of NAT genotypes in the risk of prostate cancer, with adjustment for age. We stratified the analysis according to Gleason grade, disease status, age at diagnosis (median age), and risk of disease progression (PSA higher than $10 \mathrm{mg} / \mathrm{ml}$ ).

\section{RESULTS}

The frequencies of NAT1 genotypes in prostate cancer cases and controls are shown in Table I. The most common genotype was $N A T 1^{*} 4 / N A T 1 * 4$ both in cases $(73.6 \%)$ and controls (75.2\%). The NAT1*11 allele was rare in controls $(0.7 \%)$ and was not found in the case groups. The frequency of $N A T 1^{*} 10$ genotypes was similar between cases and controls. There were not statistically significant differences in NAT1 genotypes between prostate cancer patients and healthy individuals.

The frequency of NAT2 genotypes in cases and controls is shown in Table II. A statistically significant difference was observed in the frequency of a NAT2 slow acetylator genotype, $N A T 2^{*} 6 / N A T 2^{*} 6$, in prostate cancer patients (3.4\%) when compared with the control group $(10.3 \%)(P=0.017 ; \mathrm{OR}=0.31,95 \% \mathrm{CI} 0.11-0.84)$.

TABLE I. NATI Genotype Frequencies in Prostate Cancer Cases and Controls With Odds Ratio (OR)

\begin{tabular}{|c|c|c|c|c|c|c|}
\hline \multirow[b]{2}{*}{ NAT1 genotype } & \multicolumn{2}{|c|}{ Cases } & \multicolumn{2}{|c|}{ Controls } & \multirow[b]{2}{*}{ OR $(95 \% \mathrm{CI})^{\mathrm{a}}$} & \multirow[b]{2}{*}{$P$} \\
\hline & $\mathrm{n}$ & $\%$ & $\mathrm{n}$ & $\%$ & & \\
\hline$N A T 1^{*} 4 / N A T 1 * 4$ & 95 & 73.6 & 109 & 75.2 & $0.92(0.53-1.58)$ & 0.772 \\
\hline$N A T 1 * 4 / N A T 1 * 10$ & 26 & 20.2 & 29 & 20.0 & $1.01(0.55-1.82)$ & 0.974 \\
\hline NAT1*10/NAT1*11 & 0 & 0 & 1 & 0.7 & - & 0.345 \\
\hline NAT1*10/NAT1*10 & 6 & 4.7 & 6 & 4.1 & $1.13(0.35-3.59)$ & 0.836 \\
\hline
\end{tabular}

${ }^{\mathrm{a}} \mathrm{OR}$ were calculated from the ratio of the number of genotypes in interest versus all the other genotypes. 
TABLE II. NAT2 Genotype Frequencies in Prostate Cancer Cases and Controls With OR

\begin{tabular}{|c|c|c|c|c|c|c|}
\hline \multirow[b]{2}{*}{ NAT2 genotype } & \multicolumn{2}{|c|}{ Cases } & \multicolumn{2}{|c|}{ Controls } & \multirow[b]{2}{*}{ OR $(95 \% \mathrm{CI})^{\mathrm{a}}$} & \multirow[b]{2}{*}{$P$} \\
\hline & $\mathrm{n}$ & $\%$ & $\mathrm{n}$ & $\%$ & & \\
\hline$N A T 2 * 4 / N A T 2 * 4$ & 9 & 6.2 & 9 & 5.2 & $1.20(0.46-3.11)$ & 0.701 \\
\hline$N A T 2 * 4 / N A T 2 * 5$ & 39 & 26.7 & 54 & 31.0 & $0.81(0.49-1.31)$ & 0.396 \\
\hline$N A T 2 * 4 / N A T 2 * 6$ & 38 & 26.0 & 32 & 18.4 & $1.56(0.091-2.66)$ & 0.100 \\
\hline$N A T 2 * 5 / N A T 2 * 6$ & 31 & 21.1 & 37 & 21.3 & $0.99(0.058-1.70)$ & 0.995 \\
\hline$N A T 2 * 5 / N A T 2 * 5$ & 24 & 16.4 & 24 & 13.8 & $1.23(0.66-2.27)$ & 0.509 \\
\hline$N A T 2 * 6 / N A T 2 * 6$ & 5 & 3.4 & 18 & 10.3 & $0.31(0.11-0.84)^{\mathrm{b}}$ & 0.017 \\
\hline
\end{tabular}

${ }^{\mathrm{a}} \mathrm{OR}$ was calculated from the ratio of the number of genotypes in interest versus all the other genotypes.

${ }^{b}$ Adjusted OR for age (logistic regression analysis): $\mathrm{OR}=0.32,95 \% \mathrm{CI} 0.12-0.89 ; P=0.03$.

Multivariate logistic regression analysis confirmed this association of $N A T 2 * 6 / N A T 2 * 6$ genotype with prostate cancer protection $(P=0.030 ; \mathrm{OR}=0.32,95 \% \mathrm{CI} 0.12$ 0.89 ).

The association of NAT1 genotypes and clinicopathologic features of prostate cancer cases studied is shown in Table III. No differences were found in the frequencies of NAT1 genotypes regarding median age of diagnosis, Gleason grade, disease status (advanced or localized), and PSA levels. The same results were obtained considering NAT2 genotypes (Table IV). However, NAT2*6/NAT2*6 genotype frequency was higher in prostate cancer patients with PSA levels lower than $10 \mathrm{mg} / \mathrm{ml}$, with suggestive statistical significance $(P=0.054)$.

\section{DISCUSSION}

Prostate cancer appears to be dependent on the interaction between environmental and genetics factors, particularly dietary [21]. Several studies reported that diet could alter steroid hormonal profile and modify prostate cancer risk [22]. It has been proposed that heterocyclic amines and polycyclic hydrocarbons, which are produced by cooking meat at high temperature, act as carcinogens in prostate cancer carcinogenesis [5,17].

TABLE III. Association of NATI Genotypes With the Clinical and Pathological Features of Prostate Cancer Cases Studied

\begin{tabular}{|c|c|c|c|c|c|c|c|c|}
\hline & \multicolumn{8}{|c|}{ NAT1 genotypes } \\
\hline & \multicolumn{2}{|c|}{$N A T 1 * 4 / N A T 1 * 4$} & \multicolumn{2}{|c|}{$N A T 1^{*} 4 / N A T 1^{*} 10$} & \multicolumn{2}{|c|}{$N A T 1^{*} 4 / N A T 1^{*} 11$} & \multicolumn{2}{|c|}{ NAT $^{*} 10 /$ NAT1 $^{*} 10$} \\
\hline & $\mathrm{n}(\%)$ & $P$ value & $\mathrm{n}(\%)$ & $P$ value & $\mathrm{n}(\%)$ & $P$ value & $\mathrm{n}(\%)$ & $P$ value \\
\hline \multicolumn{9}{|l|}{ Median age } \\
\hline Age > 66 & $40(71.4)$ & \multirow[b]{2}{*}{0.607} & $13(23.2)$ & \multirow[b]{2}{*}{0.448} & $1(1.8)$ & \multirow[b]{2}{*}{0.682} & $2(3.6)$ & \multirow[b]{2}{*}{0.472} \\
\hline Age $\leq 66$ & $55(75.3)$ & & $13(17.8)$ & & $1(1.4)$ & & $4(5.5)$ & \\
\hline \multicolumn{9}{|l|}{ Gleason grade } \\
\hline Gleason >7 & $15(78.9)$ & \multirow[b]{2}{*}{0.422} & $2(10.5)$ & \multirow[b]{2}{*}{0.209} & $1(5.3)$ & \multirow[b]{2}{*}{0.284} & $1(5.3)$ & \multirow[b]{2}{*}{0.571} \\
\hline Gleason $\leq 7$ & 77 (73.3) & & $23(21.9)$ & & $1(1.0)$ & & $4(3.8)$ & \\
\hline \multicolumn{9}{|l|}{ PSA levels } \\
\hline PSA >10 & $64(72.7)$ & \multirow[b]{2}{*}{0.741} & 19 (21.6) & \multirow[b]{2}{*}{0.964} & $2(2.3)$ & \multirow[b]{2}{*}{0.527} & $3(3.4)$ & \multirow[b]{2}{*}{0.202} \\
\hline PSA $\leq 10$ & $27(69.7)$ & & $3(21.2)$ & & $0(0.0)$ & & $3(9.1)$ & \\
\hline \multicolumn{9}{|l|}{ Disease status } \\
\hline Advanced & $44(69.8)$ & \multirow[b]{2}{*}{0.338} & $13(20.6)$ & \multirow[b]{2}{*}{0.894} & $1(1.6)$ & \multirow[b]{2}{*}{0.740} & $5(7.9)$ & \multirow[b]{2}{*}{0.094} \\
\hline Localized & $51(77.3)$ & & $13(19.7)$ & & $1(1.5)$ & & $1(1.5)$ & \\
\hline
\end{tabular}


TABLE IV. Association of NAT2 Genotypes With the Clinical and Pathological Features of Prostate Cancer Cases Studied

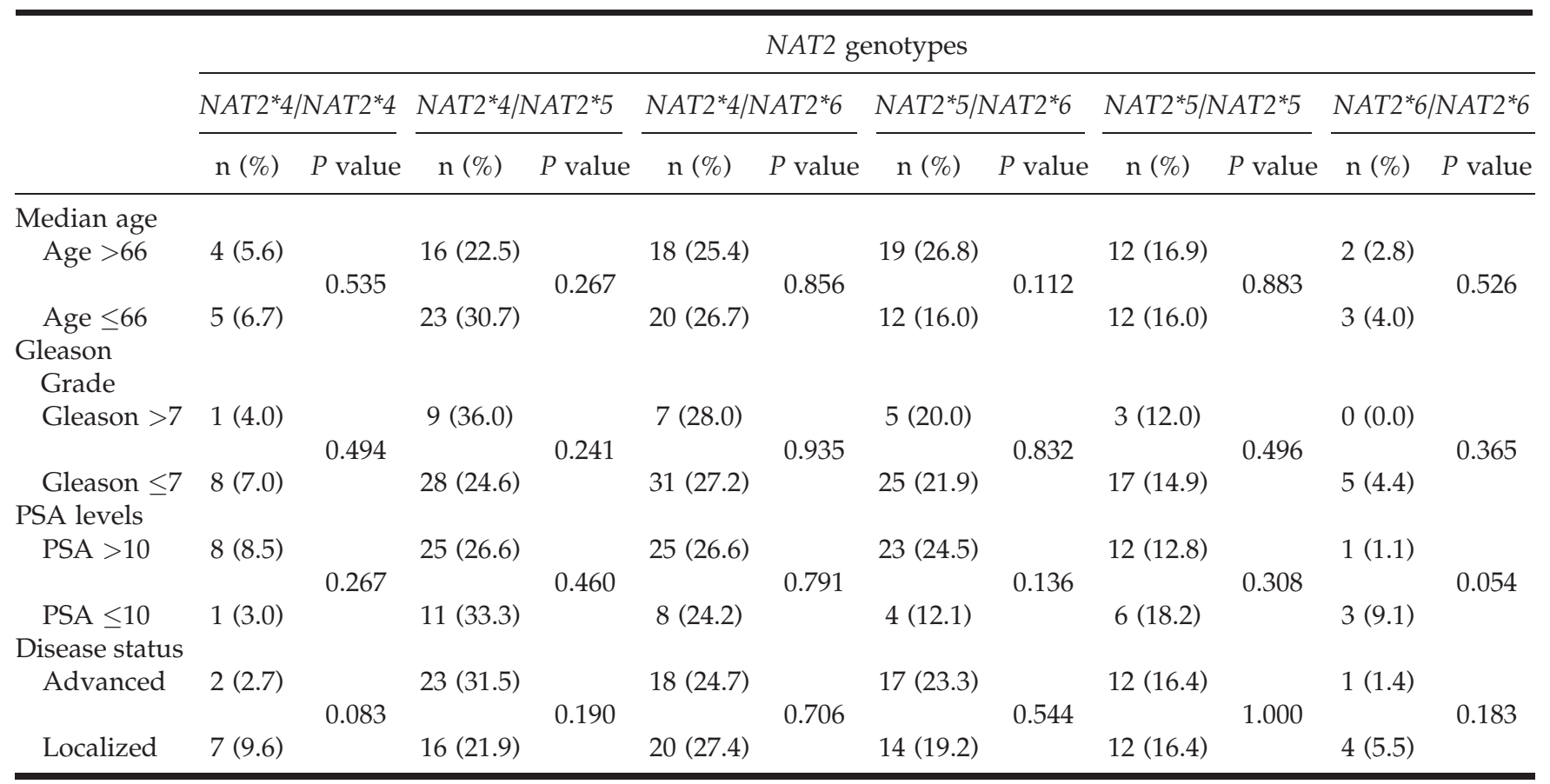

NAT enzymes are involved in the metabolism of many carcinogens, including heterocyclic amines present in cooking meat at high temperature $[4,17]$. Both NAT1 and NAT2 are responsible for both $N$-acetylation (usually deactivation) and $\mathrm{O}$-acetylation (usually activation) activities of aromatic and heterocyclic amines carcinogens [23]. Another fact that should be taken in consideration is that prostate cancer has been associated with genetic alterations that include regions of deletions on different chromosomal regions, such as $8 p$ 22-23 [24], which is the region of NAT genes [7]. Therefore, we hypothesise that NAT1 and NAT2 acetylator genotypes could be associated with susceptibility to prostate cancer.

We observed no association between NAT1 polymorphism and prostate cancer susceptibility. Controversial results have been reported regarding the role of NAT1 and NAT2 in the susceptibility to prostate cancer $[10,25,26]$. Previous reports presenting different results $[10,27]$, could be explained by the geographic difference between populations, since the frequencies of NAT1 and NAT2 polymorphisms differ greatly with ethnical characteristics [8]. In our results, the NAT2 slow acetylator genotypes, NAT2*6NAT2*6, was significantly associated with prostate cancer $(P=0.030$; $\mathrm{OR}=0.32,95 \% \mathrm{CI} 0.12-0.89$ ). It is well known that this slow acetylator genotype presents a lower enzyme activity than rapid genotypes [28]. Individuals that present this genotype show a lower capacity of metabolizing carcinogens. Many $N$-hydroxy heterocyclic amines, carcinogens are metabolically activated to a great extent by NAT2 [6,29], and these carcinogens seem to be of potential carcinogenicity to human prostate epithelial cells $[5,17]$. Therefore, carriers of $N A T 2{ }^{*} 6 N A T 2 * 6$ genotype have a lower capacity to activate carcinogens. This is consistent with the protective effect of $N A T 2 * 6 / N A T 2 * 6$ genotype to prostate cancer that we reported in our study. Furthermore, we found that $N A T 2^{*} 6 / N A T 2^{*} 6$ genotype is overrepresented in the group of prostate cancer patients with PSA levels lower than $10 \mathrm{mg} / \mathrm{ml}$ in comparison with patients with PSA levels higher than $10 \mathrm{mg} / \mathrm{ml}$. This reinforces a role for $N A T 2 * 6 N A T 2 * 6$ genotype in the prostate cancer biology.

Several reports have shown the contribution of genetic polymorphisms to the risk of prostate cancer [30-35]. Our study brings new reports that may help to clarify the function of NAT polymorphisms in prostate cancer development. Our results suggest a role of NAT2 polymorphisms in the carcinogenic pathway of prostate cancer in a population of Southern Europe. Future studies concerning the association of NAT genotypes and environmental or lifestyle factors (e.g., diet) will be important to elucidate the real meaning of NAT polymorphisms in the susceptibility to prostate cancer.

\section{ACKNOWLEDGMENTS}

The authors thank the Liga Portuguesa Contra o Cancro-Centro Regional do Norte (Portuguese 
League Against Cancer), for their support. We also thank Dr. Carlos Torres and Dr. Isabel Torres for their helpful assistance in the management of normal controls.

\section{REFERENCES}

1. Pinheiro PS, Tycznski JE, Bray F, Amado J, Matos E, Parkin DM. Cancer incidence and mortality in Portugal. Eur J Cancer 2003; 39:2507-2520.

2. Hanchette CL, Schwartz GG. Geographic patterns of prostate cancer mortality. Evidence for a protective effect of ultraviolet radiation. Cancer 1992;70:2861-2869.

3. Rodriguez C, Tatham LM, Thun MJ, Calle EE, Heath CW Jr. Smoking and fatal prostate cancer in a large cohort of adult men. Am J Epidemiol 1997;145:466-475.

4. Kolonel LN. Fat, meat, and prostate cancer. Epidemiol Rev 2001;23:72-81.

5. Wang CY, Debiec-Rychter M, Schut HA, Morse P, Jones RF, Archer C, King CM, Haas GP. $N$-acetyltransferase expression and DNA binding of $N$-hydroxyheterocyclic amines in human prostate epithelium. Carcinogenesis 1999;20:1591-1595.

6. Hein DW, Doll MA, Rustan TD, Gray K, Feng Y, Ferguson RJ, Grant DM. Metabolic activation and deactivation of arylamine carcinogens by recombinant human NAT1 and polymorphic NAT2 acetyltransferases. Carcinogenesis 1993;14:1633-1638.

7. Blum M, Grant DM, McBride W, Heim M, Meyer UA. Human arylamine $\mathrm{N}$-acetyltransferase genes: Isolation, chromosomal localization, and functional expression. DNA Cell Biol 1990; 9:193-203.

8. Butcher NJ, Boukouvala S, Sim E, Minchin RF. Pharmacogenetics of the arylamine $N$-acetyltransferases. Pharmacogenomics J 2002; 2:30-42.

9. Garte S, Gaspari L, Alexandrie AK, Ambrosone C, Autrup H, Autrup JL, Baranova H, Bathum L, Benhamou S, Boffetta P, Bouchardy C, Breskvar K, Brockmoller J, Cascorbi I, Clapper ML, Coutelle C, Daly A, Dell'Omo M, Dolzan V, Dresler CM, Fryer A, Haugen A, Hein DW, Hildesheim A, Hirvonen A, Hsieh LL, Ingelman-Sundberg M, Kalina I, Kang D, Kihara M, Kiyohara C, Kremers P, Lazarus P, Le Marchand L, Lechner MC, van Lieshout EM, London S, Manni JJ, Maugard CM, Morita S, Nazar-Stewart V, Noda K, Oda Y, Parl FF, Pastorelli R, Persson I, Peters WH, Rannug A, Rebbeck T, Risch A, Roelandt L, Romkes M, Ryberg D, Salagovic J, Schoket B, Seidegard J, Shields PG, Sim E, Sinnet D, Strange RC, Stucker I, Sugimura H, To-Figueras J, Vineis $\mathrm{P}, \mathrm{Yu}$ MC, Taioli E. Metabolic gene polymorphism frequencies in control populations. Cancer Epidemiol Biomarkers Prev 2001;10:1239-1248.

10. Hein DW, Leff MA, Ishibe N, Sinha R, Frazier HA, Doll MA, Xiao GH, Weinrich MC, Caporaso NE. Association of prostate cancer with rapid $N$-acetyltransferase 1 (NAT1*10) in combination with slow $\mathrm{N}$-acetyltransferase 2 acetylator genotypes in a pilot casecontrol study. Environ Mol Mutagen 2002;40:161-167.

11. Hou SM, Ryberg D, Falt S, Deverill A, Tefre T, Borresen AL, Haugen A, Lambert B. GSTM1 and NAT2 polymorphisms in operable and non-operable lung cancer patients. Carcinogenesis 2000;21:49-54.

12. van der Hel OL, Peeters PH, Hein DW, Doll MA, Grobbee DE, Kromhout D, Bueno de Mesquita HB. NAT2 slow acetylation and GSTM1 null genotypes may increase postmenopausal breast cancer risk in long-term smoking women. Pharmacogenetics 2003;13:399-407.
13. Costa S, Medeiros R, Vasconcelos A, Pinto D, Lopes C. A slow acetylator genotype associated with an increased risk of advanced cervical cancer. J Cancer Res Clin Oncol 2002;128: 678-682.

14. Hung RJ, Boffetta P, Brennan P, Malaveille C, Hautefeuille A, Donato F, Gelatti U, Spaliviero M, Placidi D, Carta A, Scotto dC, Porru S. GST, NAT, SULT1A1, CYP1B1 genetic polymorphisms, interactions with environmental exposures and bladder cancer risk in a high-risk population. Int J Cancer 2004;110: 598-604.

15. Brockton N, Little J, Sharp L, Cotton SC. N-acetyltransferase polymorphisms and colorectal cancer: A HuGE review. Am J Epidemiol 2000;151:846-861.

16. Payton MA, Sim E. Genotyping human arylamine $N$-acetyltransferase type 1 (NAT1): The identification of two novel allelic variants. Biochem Pharmacol 1998;55:361-366.

17. Lawson T, Kolar C. Human prostate epithelial cells metabolize chemicals of dietary origin to mutagens. Cancer Lett 2002;175: 141-146.

18. Mullenbach R, Lagoda PJ, Welter C. An efficient salt-chloroform extraction of DNA from blood and tissues. Trends Genet 1989; 5:391.

19. Bell DA, Badawi AF, Lang NP, Ilett KF, Kadlubar FF, Hirvonen A. Polymorphism in the $N$-acetyltransferase 1 (NAT1) polyadenylation signal: Association of $\mathrm{NAT}^{*} 10$ allele with higher $\mathrm{N}$-acetylation activity in bladder and colon tissue. Cancer Res 1995;55:5226-5229.

20. Gonzalez MV, Alvarez V, Pello MF, Menendez MJ, Suarez C, Coto E. Genetic polymorphism of $N$-acetyltransferase-2, glutathione S-transferase-M1, and cytochromes P450IIE1 and P450IID6 in the susceptibility to head and neck cancer. J Clin Pathol 1998;51:294-298.

21. Pienta KJ, Esper PS. Risk factors for prostate cancer. Ann Intern Med 1993;118:793-803.

22. Ross RK, Henderson BE. Do diet and androgens alter prostate cancer risk via a common etiologic pathway? J Natl Cancer Inst 1994;86:252-254.

23. King CM, Land SJ, Jones RF, Debiec-Rychter M, Lee MS, Wang CY. Role of acetyltransferases in the metabolism and carcinogenicity of aromatic amines. Mutat Res 1997;376:123128.

24. Xu J, Zheng SL, Hawkins GA, Faith DA, Kelly B, Isaacs SD, Wiley KE, Chang B, Ewing CM, Bujnovszky P, Carpten JD, Bleecker ER, Walsh PC, Trent JM, Meyers DA, Isaacs WB. Linkage and association studies of prostate cancer susceptibility: Evidence for linkage at 8p22-23. Am J Hum Genet 2001;69: 341-350.

25. Wadelius M, Autrup JL, Stubbins MJ, Andersson SO, Johansson JE, Wadelius C, Wolf CR, Autrup H, Rane A. Polymorphisms in NAT2, CYP2D6, CYP2C19 and GSTP1 and their association with prostate cancer. Pharmacogenetics 1999;9:333-340.

26. Hamasaki $\mathrm{T}$, Inatomi $\mathrm{H}, \mathrm{Katoh} \mathrm{T}$, Aono $\mathrm{H}$, Ikuyama $\mathrm{T}$, Muratani T, Matsumoto T. $N$-acetyltransferase-2 gene polymorphism as a possible biomarker for prostate cancer in Japanese men. Int J Urol 2003;10:167-173.

27. Fukutome $\mathrm{K}$, Watanabe $\mathrm{M}$, Shiraishi T, Murata M, Uemura $\mathrm{H}$, Kubota Y, Kawamura J, Ito H, Yatani R. $N$-acetyltransferase 1 genetic polymorphism influences the risk of prostate cancer development. Cancer Lett 1999;136:83-87.

28. Cascorbi I, Drakoulis N, Brockmoller J, Maurer A, Sperling K, Roots I. Arylamine $N$-acetyltransferase (NAT2) mutations and their allelic linkage in unrelated Caucasian individuals: 
Correlation with phenotypic activity. Am J Hum Genet 1995;57: 581-592.

29. Hein DW, Rustan TD, Ferguson RJ, Doll MA, Gray K. Metabolic activation of aromatic and heterocyclic $N$-hydroxyarylamines by wild-type and mutant recombinant human NAT1 and NAT2 acetyltransferases. Arch Toxicol 1994;68:129-133.

30. Medeiros R, Morais A, Vasconcelos A, Costa S, Pinto D, Oliveira $\mathrm{J}$, Lopes $\mathrm{C}$. The role of vitamin D receptor gene polymorphisms in the susceptibility to prostate cancer of a southern European population. J Hum Genet 2002;47:413-418.

31. Medeiros R, Morais A, Vasconcelos A, Costa S, Pinto D, Oliveira J, Lopes C. Endothelial nitric oxide synthase gene polymorphisms and genetic susceptibility to prostate cancer. Eur J Cancer Prev 2002;11:343-350.

32. Medeiros R, Morais A, Vasconcelos A, Costa S, Pinto D, Oliveira J, Carvalho R, Lopes C. Linkage between polymorphisms in the prostate specific antigen ARE1 gene region, prostate cancer risk, and circulating tumor cells. Prostate 2002;53: 88-94.

33. Ferreira PM, Medeiros R, Vasconcelos A, Costa S, Pinto D, Morais A, Oliveira J, Lopes C. Association between CYP2E1 polymorphisms and susceptibility to prostate cancer. Eur J Cancer Prev 2003;12:205-211.

34. Medeiros R, Vasconcelos A, Costa S, Pinto D, Ferreira P, Lobo F, Morais A, Oliveira J, Lopes C. Metabolic susceptibility genes and prostate cancer risk in a southern European population: The role of glutathione S-transferases GSTM1, GSTM3, and GSTT1 genetic polymorphisms. Prostate 2004;58:414-420.

35. Ribeiro R, Vasconcelos A, Costa S, Pinto D, Morais A, Oliveira J, Lobo F, Lopes C, Medeiros R. Overexpressing leptin genetic polymorphism $(-2548 \mathrm{G} / \mathrm{A})$ is associated with susceptibility to prostate cancer and risk of advanced disease. Prostate 2004; $59: 268-274$. 